\title{
Sodium Valproate in the Treatment of the Intractable Childhood Epileptic
}

\author{
D.L. KEENE, K. METRAKOS, G.V. WATTERS and A. SHERWIN
}

SUMMARY: Sixty-five children with seizure disorders, who had been treated with multiple anticonvulsants but were poorly controlled, were selected from the Montreal Children's Hospital Convulsive Disorder Clinic and Neurology Service and were treated with sodium valproate (valproate). All types of seizure disorders were included in the group.

Rapid oral absorption of the drug lead to peak plasma levels in one to three hours (later peaks occurring if administered after meals). A mean plasma half-life of 12.8 hours was calculated. Correlation between

RESUME: Nous avons traité avec le sodium valproate 65 enfants épileptiques qui avaient recus de multiples anticonvulsivants, mais dont le contrôle était insuffisant. Toutes les formes de crises épileptiques se retrouvent dans ce groupe.

Une absorption orale rapide du médicament produit un taux maximum en une à 3 heures (plus tardivement si consommé avec les repas). Nous avons calculé une demie-vie plasmatique de 12.8 heures. La corrélation entre la dose orale et le taux plasmatique était généralement pauvre. Il y oral dose and plasma levels was poor. The side effects which occurred in this study were trivial. Drug interactions occurred with phenobarbital, diphenylhydantoin and clonazepam.

Sixty percent of patients had a greater than $50 \%$ reduction in seizure frequency with sodium valproate, but the best response was in generalized absence seizures. Since all types of seizures responded to some degree, a trial of sodium valproate is warranted in intractable seizure disorders of childhood regardless of classification.

eut très peu d'effets secondaires, de faible importance. Il y eut des interactions médicamenteuses avec le phénobarbital, la diphenylhydantoine et le clonazepam.

$60 \%$ des patients ont eu une réduction de plus de $50 \%$ de leurs crises, particulièrement des crises d'absences généralisées. Puisqu'il y eut réponse chez tous les groupes, nous suggérons d'employer le valproate chez les patients dont les crises sont incontrôlées, peu importe leur classification.

\section{INTRODUCTION}

Sodium valproate (valproate) has been in use as an organic solvent since 1881 , but it was only in 1963 that Meunier et al. (1963) discovered its antiepileptic properties in animals. That year, Carraz et al. (1964) reported on the first clinical trial of this drug. He noted that the drug was effective against all seizure types and had no major side effects. Numerous reports have since been published attesting to its excellent anticonvulsant properties, particularly in the treatment of the absence seizures, while a few have reported serious side effects.

Because of this favourable experience and because there were many children with intractable seizure disorders being treated at the Montreal Children's Hospital, a trial of valproate was begun in 65 of these patients. The purpose of this paper is to report our findings in the control of all types of seizures in childhood. This study involved children of normal and subnormal intelligence, and reports side effects of valproate and its interaction with other drugs.

\section{METHODS}

Informed consent was obtained from parents prior to the onset of the study. Blood for complete blood count, platelets, serum glutamic oxaloacetic transaminase, total bilirubin, lactic dehydrogenase, total protein, albumin, blood urea nitrogen, glucose, creatinine, electrolytes, and serum anticonvulsant levels was obtained before starting valproate, again at six weeks after starting the drug, and thereafter at six month intervals. A 30 minute monopolar-bipolar EEG recording using stardard 10-20 system of electrode placement was done just prior to starting valproate, again six weeks after starting valproate and then at three month intervals. 
The study was divided into three consecutive phases. During phase one (first six weeks), the parents recorded the child's seizure pattern and frequency while continuing his usual anticonvulsant medications. This was a baseline for future comparison.

During phase two, valproate was begun at $15 \mathrm{mg} / \mathrm{kg} /$ day in addition to regular anticonvulsant medications. Valproate was gradually increased over three weeks to $30 \mathrm{mg} / \mathrm{kg} / \mathrm{day}$ (given in three divided doses). The parents continued to record the child's seizure frequency and pattern.

After three months, if there had been a greater than $50 \%$ reduction in the child's seizure frequency, phase three of the study was entered. During this period, an attempt was made to use valproate as the only anticonvulsant. This was done by slowly tapering the dosage of the other anticonvulsant medications, while maintaining good seizure control as judged by the child's seizure frequency chart.

Pharmokinetic studies were carried out in 15 children randomly chosen at the onset of the study. All were on multiple drugs and had been for some time. Baseline anticonvulsant levels were obtained before an oral loading dose of 30 $\mathrm{mgm} / \mathrm{kg}$. valproate was given. At one, two, four, six, eight, ten and twentyfour hours, repeat blood samples for valproate plasma levels were obtained. From this data, standard absorption and half life curves were constructed. Serum valproate plasma levels were determined by gas chromatography (Odusote et al, 1981).

\section{PATIENTS SELECTED FOR STUDY}

Patients under 20 years of age with greater than four seizures per month despite adequate standard anticonvulsant medications and without signs of progressive neurological disorder were admitted to the study. Sixty-five patients (36 males; 29 females) comprised the study. They varied in age from 2 to 20 years (mean age: 12 years), with age of onset of clinical seizures from birth to midteens (mean age: 3-6 years). The mean duration of their seizure history was eight years (range 1-20 years). Most of them were taking multiple anticonvulsants (up to five) each day, (average 2.4). Most had tried many other drug combinations in the past.

The level of intelligence of the patients varied. Fourteen were in regular classes in regular schools; ten in special classes in regular schools; 13 were in special schools for the mentally handicapped; 19 needed institutional care because of their degree of mental retardation; four were too young to go to school.

Clinical seizure patterns and interictal EEG abnormalities were often complex and changing with time. This made individual seizure classification difficult. In this study, each patient was classified according to the pattern at the time of admission to the study. (Tables I and II).

\section{RESULTS}

Thirty-eight patients (58\%) had a greater than $50 \%$ reduction in their overall seizure frequency; of these $31 \%$ had a $90-100 \%$ reduction in frequency. When major seizure pattern at time of entry to the study was considered, those patients with generalized absence seizures did best not only in reduction of seizure frequency, but also in the achievement of good clinical control. This was true with valproate alone or in conjunction with a reduction in the number of anticonvulsants (Tables III and IV). The patients that did not respond at all to valproate were those in whom the initial seizures were infantile spasms. The best seizure control was achieved by doses around $30 \mathrm{mg} / \mathrm{kg} /$ day; a better response was not seen with a higher dose in any case.
TABLE I

Comparison of the major clinical seizure pattern in 65 patients at time of original diagnosis and at time of entering the study.

Seizure Pattern
Partial complex
Partial elementary
Generalized tonic-clonic
Generalized absence
Infantile spasms

Percent of Patients in Each Category Originally At Present

55

$29 \quad 34$

$31 \quad 35$

$18 \quad 26$

$17 \quad 0$

\section{TABLE II}

Comparison of the major EEG pattern at the time of the original diagnosis and at time of entering into the study.

\section{EEG Pattern}

Normal

Nonspecific disturbance

Paroxysmal disturbance

Generalized spike wave

epileptiform disturbance

Focal epileptiform disturbance

Hypsarrhythmia

\section{Percent of Patients in Each Category} Originally At Present

$\begin{array}{rr}4.5 & 3 \\ 20.0 & 10.8 \\ 3.0 & 1.5 \\ & \\ 32.0 & 44.0 \\ 37.0 & 38.0 \\ 3.0 & 1.5\end{array}$


TABLE III

Reduction in seizure frequency for the various clinical seizure patterns.

$\begin{array}{lccc}\text { Seizure Pattern } & \begin{array}{c}\text { No. of } \\ \text { Patients }\end{array} & \begin{array}{c}\text { \%ith } \\ \text { greater } \\ \text { than 90\% } \\ \text { Reduction }\end{array} & \begin{array}{c}\text { \% with } \\ \text { greater } \\ \text { than 50\% } \\ \text { Reduction }\end{array} \\ \text { Partial complex } & 3 & 0 & 67 \\ \text { Partial elementary } & 22 & 14 & 41 \\ \text { Generalized tonic-clonic } & 23 & 39 & 57 \\ \text { Generalized absence } & 17 & 53 & 82\end{array}$

TABLE IV

The ability to decrease other anticonvulsant medications or use sodium valproate alone after 6 months for the various clinical seizure patterns.

$\begin{array}{lccc}\text { Seizure Pattern } & \begin{array}{c}\text { No. of } \\ \text { Patients }\end{array} & \begin{array}{c}\text { \% on } \\ \text { Valproate } \\ \text { only }\end{array} & \begin{array}{c}\text { \% on Valproate } \\ \text { with decrease in } \\ \text { other Medications }\end{array} \\ \text { Partial elementary } & 22 & 0 & 18 \\ \text { Partial complex } & 3 & 33 & 6 \\ \text { Generalized absence } & 17 & 29 & 64 \\ \text { Generalized tonic clonic } & 23 & 13 & 6\end{array}$

TABLE V

Frequency of adverse reactions to Sodium Valproate in 65 patients.

Sedation

Diarrhea

Nausea

Behavioural Changes

Hair Loss

Rash

Decreased Platelets

Liver Enzyme Abnormalities

$\%$ of Patients Showing one or more Adverse Effects

TABLE VI

The Changes in blood levels of other anticonvulsants after starting Sodium Valproate.

\begin{tabular}{|c|c|c|c|c|}
\hline Drug & $\begin{array}{l}\text { No. of } \\
\text { Patients } \\
\text { on Drug }\end{array}$ & $\begin{array}{l}\text { \% Patients } \\
\text { with an } \\
\text { Increased } \\
\text { Blood } \\
\text { Level }\end{array}$ & $\begin{array}{l}\text { \% Patients } \\
\text { with } \\
\text { Unchanged } \\
\text { Blood } \\
\text { Level }\end{array}$ & $\begin{array}{l}\text { \% Patients } \\
\text { with } \\
\text { d Decreased } \\
\text { Blood } \\
\text { Level }\end{array}$ \\
\hline Phenobarbital & 20 & 85 & 10 & 5 \\
\hline Primidone & 17 & 76 & 24 & 0 \\
\hline Diphenylhydantoin & 43 & 42 & 18 & 40 \\
\hline Ethosuzimide & 30 & 0 & 100 & 0 \\
\hline Carbamazepine & 34 & 0 & 100 & 0 \\
\hline
\end{tabular}

Comparing children in regular classes in regular schools with those in special schools for the mentally retarded, and in turn with those in institutions for the mentally retarded, there was a slight but not significant difference in the percentage of children obtaining greater than $50 \%$ improvement in seizure frequency after addition of valproate $(64 \%, 69 \%, 47 \%$ respectively). In contrast, $80 \%$ of the group in special classes in regular schools had a greater than $50 \%$ improvement in their overall seizure frequency after starting valproate. This group had the highest incidence of generalized seizure disorder which may be the discriminant factor for this group.

Though changes in the patients' intellectual function were not specifically looked for in this study, many teachers and parents volunteered that the children were more alert and aware after starting valproate. This did not appear to be related simply to a reduction in seizure frequency nor to a reduction in other anticonvulsant medication, although these probably contributed.

Adverse reactions seen in this particular study were minor. In the 21 patients with side effects sedation was the most common complaint (Table V). With reduction of phenobarbital the problem quickly resolved in all but one. In that patient, valproate alone proved to be the responsible agent, for when it was given alone the patient became stuporous within 48 hours with a high voltage generalized delta wave disturbance noted in the EEG. Within a further 48 hours of stopping the valproate, the patient returned to his usual state of awareness.

Gastric upset which occurred in $8 \%$ of the patients disappeared in some if the drug was taken with a meal. In others the dosage had to be decreased and gradually increased again, usually without any problems the second time.

Drug interactions with phenobarbital, primidone, clonazepam, and phenytoin were seen (Table VI). Phenobarbital and primidone plasma levels were elevated in the majority after starting valproate. This necessitated the reduction of primidone and /or phenobarbital in these patients. Phenytoin levels rose in $42 \%$ of the 
patients and fell in $49 \%$ after starting valproate.

After the introduction of valproate, withdrawal of clonazepam led to a marked increase in seizure frequency in seven patients and three of these at the same time became psychotic. One week following the withdrawal of clonazepam, their behaviour improved remarkably.

Seizure control was obtained at widely differing fasting plasma drug levels. No clear correlation between fasting plasma drug level and seizure control was found, nor was there a correlation between fasting plasma level and appearance of an adverse reaction. The same oral dosage, expressed as $\mathrm{mg} / \mathrm{kg} /$ day gave different fasting plasma levels on different days in the same patient and from patient to patient. No clear linear relationship between increasing dosage $(\mathrm{mg} / \mathrm{kg} /$ day) and fasting plasma level of the drug was observed.

Valproate taken post-prandial gave a peak plasma level around three hours, with a peak around one hour if taken fasting. The drug was rapidly eliminated from the body with a mean half-life of 12.8 hours. There was little difference for the half-life values at the various ages (Figure I).

\section{DISCUSSION}

Previous reports (Barnes et al, 1975; Haigh et al, 1975; Hassan et al, 1976; Jeavons et al, 1974; Pinder et al, 1977; Richens et al, 1979; Sherard et al, 1980; Silenpaa et al, 1976; Simon et al, 1975; Vining et al, 1979; and Volzke et al, 1973) have suggested that valproate is most effective in the child with normal neurological and intellectual functions who has a generalized form of epilepsy that began in later childhood and with a generalized spike wave EEG discharge. Though the results of this study would agree that the drug was most effective in generalized absence seizures beginning later in childhood, a poor correlation was found between the level of intellectual and/or neurological functioning and the degree of seizure control. There was also a poor correlation between EEG pattern and seizure control obtained from valproate. The results in the partial seizure disorder group were somewhat better than generally expected for this drug; but were similar to those reported by Sherard et al (1980).

In many previous studies, pediatrics and adult age groups have been analyzed together. Even in studies reporting children separately, it was difficult to identify the children who

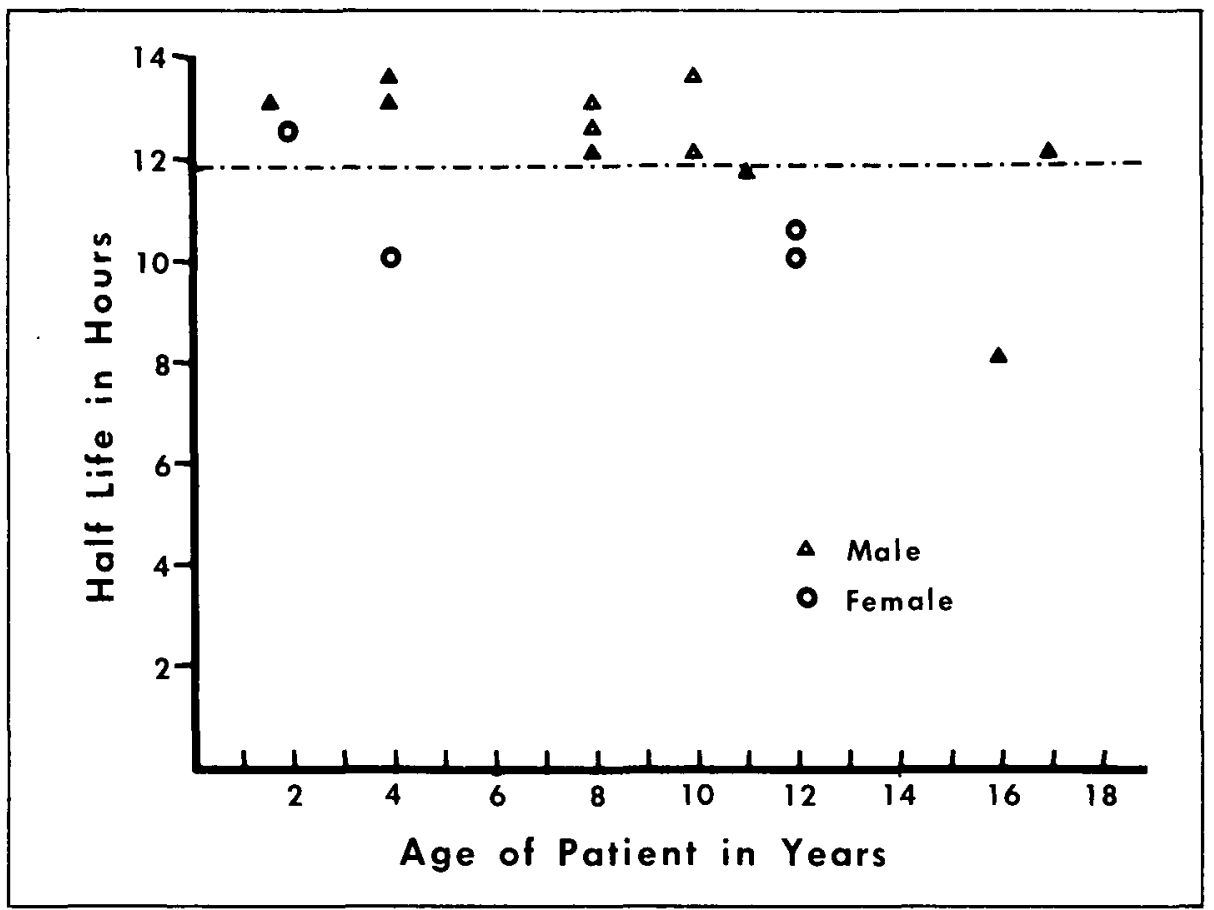

Figure 1 - Graph showing age in years versus $t / 2$ valproate.

had partial seizures. These ambiguities may account for the difference between our results and those of previous reports. Why valproate may be more effective in children than adults with partial seizure disorder is unclear, though maturation of the central nervous system may play a role.

As in previous studies, the side effects of valproate were minor. No correlation between the plasma valproate levels and side effects were seen. Sedation was the most common problem. In most cases, it was due to elevated phenobarbital plasma levels which could be prevented by decreasing the phenobarbital dosage. Not all cases of sedation were secondary to phenobarbital. Stupor has occurred in valproate treated patients in whom no other cause could be found. The reason for this is not understood but valproate toxicity has several features in common with Reye's syndrome (Gerber et al, 1979). This would suggest that valproate can temporarily lead to isolated organ or multiorgan mitochondrial failure similar to that seen in Reye's Syndrome.

The next most common problem was gastric upset. In most, this was avoided by using divided doses immediately after meals. If the problem persisted a switch from capsule to liquid form or a temporary decrease in total daily dose often helped.

Abnormal hepatic function tests were not observed in this study even though many patients were on multiple anticonvulsant medications. This, in part may be due to the low maximum daily doses of valproate utilized in this study.

The study of drug kinetics in patients taking other medications is often more difficult to interpret than when taking valproate alone. The results can also change when the patient has been taking the drug for prolonged periods of time. This is due to the changes in metabolism rates of the drug by the liver. The information obtained in these situations can still contribute to our understanding of drug kinetics and lead to improved therapy.

It was noted that despite the patient selection, the half-life peak absorption times of valproate found in this study agree with those previously reported 
(Pinder et al, 1977; Sherard et al, 1980). By using these values in combination with the established principles of anticonvulsant drug management, the administration of valproate in the pediatric population should be at intervals not longer than eight hours. Animal studies have shown that valproate enters cat brain more effectively after a sudden high plasma concentration of the drug than after a prolonged lower level.

Also, in mice, a large single dose gave a greater protective anticonvulsant effect than multiple doses. On the basis of these observations, Covanis and Jeavons (1980) gave valproate once daily, usually at night, in 35 patients with generalized seizures. The seizures were completely controlled in all, but 4 patients developed side effects. Compliance was also improved. A few of our patients tried this approach with mixed success. Side effects occurred in many patients. This method of administration requires further evaluation before general adoption can be recommended.

The interactions of phenobarbital and phenytoin with valproate seen in this study were similar to those previously reported (Wilder et al, 1978). Bruni et al (1980) have showed valproate administration is not associated with decreased renal excretion of phenobarbital, but rather a decrease in the conversion of phenobarbital to hydroxylphenyl-phenobarbital by the liver. The same investigators (Bruni et al, 1979) have shown that after the introduction of valproate in patients taking phenytoin, a transient decrease in phenytoin plasma levels occurs. This was due to displacement of phenytoin from the protein-binding sites by valproate and an increase in the free fraction of phenytoin.

The problems which several of our patients experienced on a combination of clonazepam and valproate have been previously reported (Jeavons et al, 1977). Whenever possible, clonazepam was discontinued before starting our patients on valproate.

\section{CONCLUSION}

The clinical reduction in the seizure frequency seen with all seizure types and the infrequent and minor side effects in this study of 65 children suggests that a trial of valproate is warranted in cases of intractable childhood epilepsy. The drug should be introduced slowly to minimize the side effects and should be given in three divided doses with meals. As potentially lethal hepatic and platelet dysfunction has been reported in the literature, frequent monitoring of platelets and hepatic functions should be done.

\section{ACKNOWLEDGEMENTS}

The authors wish to express their appreciation to Ms. Lacroix for her careful assays of serum valproate. Support in part by the Medical Research Council of Canada (MA 1451).

\section{REFERENCES}

BARNES, S.E. and BOWER, S.E. - "Sodium Valproate in the Treatment of Intractable Childhood Epilepsy" - Develop Med. Child. Neurol. 17:175 (1975).

BRUNI, J., WILDER, B.J., PERCHALSKI, R.J., HAMMOND, E.J., and VILLAREAL, H.J. - "Valproic Acid and Plasma Levels of Phenobarbital" - Neurol. (Minneal) 1:94 (1980).

BRUNI, J., WILDER, B.J., WILLMORE, L.J., and BARBOUR, B. - "Valproic Acid Plasma Levels of Phenytoin" - Neurol (Minneap) 29:904 (1979).

CARRAZ, G., FAU, R., ChATEAU, R. and BONNIN, J. - "Communications à propos des premiers essais cliniques sur L'activité anti-épileptique de L'acid n-dipropylacétique (sel de Na)" Ann Med. Psychol 122:577 (1964).

COVANIS, A. and JEAVONS, P.M. - "Once Daily Sodium Valproate in the Treatment of Epilepsy" - Devel. Med. Child. Neurol. 22:204 (1980).

GERBER， N., DICKINSON，R.G., HAR LAND, R.C., LYNN, R.K., HOUGHTON, D., ANTONIA, J.l. and SCHMISHOCK, J.C. - "Reye-like Syndrome Associated with Valproic Acid Therapy" $J$. Ped. 95:142 (1979).

HAIGH, D. and FORSYTHE, W.I. - "The Treatment of Childhood Epilepsy with Sodium Valproate" - Develop. Med. Child. Neurol. 17:743 (1975).

HASSAN, M.N., LALJEE, H.C.K., and PARSONAGE, M.J. - "Sodium Valproate in the
Treatment of Resistant Epilepsy" - Acta Neurol Scand. 54:209 (1976).

JEAVONS, P, and CLARK, J.E. - "Sodium Valproate in Treatment of Epilepsy" - Brit. Med.J. 2:584 (1974).

JEAVONS, P.M., CLARK, J.E. and MAHESHWASI, M.C. - "The Treatment of Generalized Epilepsies on Valproate (Epilim) - Devel. Med. Child. Neurol. 19:9 (1977).

MEUNIER, H., CARRAZ, G., NEUNIER, Y., EYMARD, $P$. and AIMARD, M. "Proprites" pharmacodynamiques de l'acid n-dipropylacetique-Therapie 18:435 (1964).

ODUSOTE, K. and SHERWIN, A. - "A Simple Direct Extraction Method for gas-liquid chromatographic Determination of Valproic Acid in Plasma" - Therapeutic Drug Monitoring 3:103 (1981).

PINDER, R.M., BRODGEN, R.N., SPEIGHT, T.M. and AVERY, G.S. "Sodium Valproate: A Review of its Pharmacological Properties and Therapeutic Efficacy in Epilepsy" - Drugs 13:81 (1977).

RICHENS, A. and AHMAD, S. - "Controlled Trial of Sodium Valproate in Severe Epilepsy"- Brit Med.J. 1:255 (1975).

RUUSKANEN, I., KILPELAINEN, J.O. and RICKKINEN, P.J. - "Side Effects of Sodium Valproate during long-term Treatment in Epilepsy" - Acta. Neurol. Scand. 60:125 (1979).

SHERARD, E.S., STEINMAN, G. and COURI, D. - "Treatment of Childhood Epilepsy with Valproic Acid: Results of the First 100 Patients in a 6 month Trial" Neurol (Minneap) 30:31 (1980).

SILLANPAA, M. and DONNER, M. - "Experiences on the use of Dipropylacetate in the Treatment of Childhood Epilepsy" Acta Paediatr. Scand. 65:209 (1976).

SIMON, D. and PENVY, J.K. - "Sodium di-Npropylacetate (DPA) in the treatment of Epilepsy, a Review" - Epilepsia 16:549 (1975).

VINING, E.P.G.I., BOTSFORD, E. and FREEMAN, J.M. - "Valproate Sodium in Refractory Seizures" - Am. J. Dis. Child 133:274 (1979).

VOLZKE, E. and DOOSE, H. - "Dipropylacetate (Depakine Ergenyl) in the Treatment of Epilepsy" - Epilepsia (Amst) $14: 185$ (1973).

WILDER, B.J., WILLMORE, L.J., BRUNI, J. and VILLAREAL, H.J. - "Valproic Acid interaction with other Anticonvulsant Drugs" - Neurol. Minneap 28:892 (1978). 